\title{
Individual Features of the Convict's Personality (Results of a Psychological Research)
}

\author{
YOANNA M. NEDYALKOVA \\ Varna Free University "Chernorizets Hrabar", Varna, Bulgaria \\ ORCID: https://orcid.ord/0000-0002-7314-625X, e-mail: retrojonni@abv.bg
}

\begin{abstract}
Introduction: the article presents a study conducted by means of a questionnaire survey among convicts in the Varna prison. The legal status of convicts affects their psychological and behavioral features. When studying the process of forming certain personal qualities in a criminal, we find it necessary to trace the interaction between society and personality. In particular, it is necessary to identify the negative impact of isolation on the convict's personality in order to work on their reformation. When working with a convicted person, it is necessary to take into account such features of their personality as orientation, abilities, and age characteristics. Such people are alienated from society and its values and have a negative self-image. The present paper focuses on the moral attitudes and knowledge of convicts and on the use of their potential and desire for personal change. In this process, a comprehensive set of intellectual and volitional qualities is formed, in which self-esteem is an important factor that determines behavior and individual features. The aim of our research is to study the level of aggression in convicts and its manifestations under the conditions of isolation; we also try to work out measures to minimize the impact of places of deprivation of liberty on an individual and their relations with others. Methods: we use the Buss-Durkee Hostility Inventory that measures aggression, and a questionnaire that helps to interview people whose behavior is of interest to researchers. Such questionnaires are designed to assess an individual's features in specific situations and allow us to ask questions directly. They are relatively straight and do not require complex electronic equipment. The studies confirm the thesis that the closeness of the convicts' stay in isolation conditions generates negative feelings, which, under specific conditions, can transform into aggressive behavior. Results: summarizing the results for aggressive manifestations of convicts' personality traits and the corresponding methods of working with convicts allow the researcher to obtain information for solving the target task. We believe that these methods can serve as a basis for building a program for psychological correction of the behavior of an individual kept in isolation.

Key words: personality; isolation; aggression; communication; self-knowledge.

19.00.06 - Legal psychology.

For citation: Nedyalkova Y.M. Individual features of the convict's personality (results of a psychological research). Penitentiary Science, 2021, vol. 15, no. 2 (54), pp. 428-433. DOI 10.46741/2686-9764-2021-15-2-428-433.
\end{abstract}

\section{Introduction}

An individual is a person who builds their own life and controls their own behavior, thereby confirming their unique presence in the world. Deviance is understood as the behavior that is opposite to the generally accepted one [12, p. 8]. In order to understand personal features of convicts, it is necessary to use different criteria. For example, from the standpoint of the socio-legal situation, such parameters as age, 
gender, severity of the crime, criminal record, and others should be considered [9].

We often observe that convicts develop individual antisocial traits and views that manifest themselves in lack of discipline, laxity, immorality, etc. [19]. The behavioral act in convicts proceeds in accordance with the scheme: stimulus - impact - immediate reaction. According to V. Frankl, noogenic neuroses arise because of existential problems rather than a conflict between primary and other types of instincts [17].

Being held behind bars blocks the individual's ability to cope on their own with compensating for the deprivations that arise in such conditions [13; 18]. However, some delinquents take responsibility for their actions and express a desire to correct their behavior.

The main aim of the research is to study aggression and personal manifestations in isolation. Tasks: 1) to review literary sources on the stated topic; 2) to organize and conduct an empirical research, prepare a questionnaire to determine the level of aggression; 3 ) to record manifestations of verbal and nonverbal aggression and the relationship between them; 4) to identify specific questions to be answered by convicts; 5) to generalize the obtained empirical results depending on the hypotheses put forward in the study.

\section{Research hypotheses}

Based on the stated goals and objectives, we put forward the following hypotheses:

1. In isolation, a deteriorated mental state contributes to increased aggressiveness [4; 11].

2. The activity of inspectors engaged in social work with convicts within the framework of group programs affects behavioral manifestations of aggression and contributes to the formation of self-control [7; 14].
3. Preventive and educational work in correctional institutions does not reform convicts' personal characteristics, but may affect their behavioral manifestation [3; 16].

\section{Methods}

The questionnaire, as a method, is used for preliminary probing mental phenomena [10]. In order to ensure that the information obtained during the survey is reliable, it is necessary to know basic requirements for its composition. There are two conditions:

- the respondent knows their own self in relation to the questions asked;

- the respondent has no grounds for misleading the researcher when answering the questions [2; $5 ; 8]$.

Convicts' self-esteem is an important regulator, but, at the same time, a significant destabilizer of behavior. Inadequate self-esteem leads to an increase in internal tension, which causes manifestations of aggression. Therefore, in the present review, we focus on taking into account characterological features of the convict's personality and his/her value orientations. According to V.A. Yadov, the art of conducting a survey consists in the ability to know what to ask and how to ask it [15].

The questionnaire helps to achieve the goal of the research since we can analyze the received answers to the questions posed. The Buss-Durkee Hostility Inventory, which measures aggression, was also used. In the Varna prison, 56 convicts were interviewed to test the general hypotheses.

\section{Discussion}

The tables show the results of the survey of respondents. Respondents could choose more than one answer.

Table 1

\begin{tabular}{|l|c|c|}
\hline \multicolumn{1}{|c|}{ Question/answers } & Amount & \% \\
\hline 1. What are the possible manifestations of aggression in prison? & 53 & 88.3 \\
\hline a) physical violence & 4 & 6.7 \\
\hline b) expression of disdain on the part of another convict & 11 & 18.3 \\
\hline c) obstruction to the achievement of the goal & 36 & 60.0 \\
\hline d) causing damage to the property of another person & 2 & 3.3 \\
\hline e) verbal attacks on another person and bullying them & 14 & 23.3 \\
\hline f) spreading malicious gossips & 2 & 3.3 \\
\hline g) refusal to defend oneself when one is blamed by another person & & 2 \\
\hline
\end{tabular}

The first question of the questionnaire was related to possible aggressive manifestations in prison. After the calculations, the answer "physical violence" showed the highest value (88.3\%), which proves that respondents often react to stress with the use of physical force. 
From the low percentage of answers to verbal attacks and accusations, it follows that indirect verbal aggression, expressed, for example, in refusing to speak in defense of another, is probably not one of the strongest aggressive trends. The second place, among the possible aggres- sive manifestations is occupied by damage to other people's property (60\%).

The next question in the questionnaire concerned the search for possible causes of aggressive behavior in prison.

Table 2

\begin{tabular}{|l|c|c|}
\hline \multicolumn{1}{|c|}{ Question/answers } & Amount & \% \\
\hline 2. What are major reasons for aggression in prison? & \multicolumn{2}{|c|}{} \\
\hline a) misunderstanding between convicts & 47 & 78.3 \\
\hline b) violence against the convict & 5 & 8.3 \\
\hline c) violation of the rights of other convicts & 4 & 6.7 \\
\hline d) violation of convicts' rights by prison administration & 46 & 76.7 \\
\hline e) disappointment with the sentence & 2 & 3.3 \\
\hline f) inability to adapt to prison conditions & 4 & 6.7 \\
\hline
\end{tabular}

The data obtained show that convicts themselves name the following reasons for the manifestation of aggression: misunderstanding, violation of their rights and difficult adaptation to the regime of the correctional institution. In conditions of penitentiary isolation, all the features of the convict's personality are enhanced and provoke an inadequate behavior model, confrontation with prison staff, unnecessary demonstrativeness and destructive behavior [9]. Withdrawal into ones' own self, preoccupation with one's own feelings and problems leads to quick and rash decisions and actions that always have the same result - the immediate satisfaction of personal ambitions and needs. Convicts are considered to be aggressive when provoked or when some of them exhibit provocative behavior.

From the standpoint of achieving one of the main goals of punishment in the form of deprivation of liberty, namely, reformation and reeducation of convicts in terms of compliance with law-abiding behavior, the answers to the following question of the questionnaire deserve attention.

Table 3

\begin{tabular}{|l|c|c|}
\hline Question/answers & Amount & $\%$ \\
\hline 3. What is most helpful in overcoming the difficulties of serving a sentence? & 43 & 72.9 \\
\hline a) encouraging measures on the part of prison administration & 3 & 5.1 \\
\hline b) necessary medical measures & 47 & 79.7 \\
\hline c) participation in cultural and educational events & 4 & 6.8 \\
\hline d) promotion of mutual understanding in the team & 4 \\
\hline
\end{tabular}

The percentage of responses to the third question shows that participation in cultural activities and employment in places of detention help to overcome the difficulties associated with the execution of sentences. Initially, the prison group (community) is a diffuse group, the relations in which are mediated only by external controlling factors. Subsequently, there emerge certain norms, goals, communication, and roles. The position of an individual in the group determines the number, content, and functions of their social contacts, which affects the dynamics of social support for the convict. The answers to the next question complement the conclusions and the picture on the previous question of the questionnaire.

Table 4

\begin{tabular}{|l|c|c|}
\hline \multicolumn{1}{|c|}{ Question/answers } & Amount & $\%$ \\
\hline 4. What is most helpful in overcoming aggression in prison? & 55 & 94.8 \\
\hline a) community engagement & 3 & 5.2 \\
\hline б) the opportunity for the convict to be alone with themselves & 3 & \multicolumn{2}{|c|}{} \\
\hline
\end{tabular}


It is obvious that convicts have a positive attitude toward collective forms of interaction that contribute to reducing stress in everyday life, promote adequate self-presentation and self-affirmation. This provides convicts with an opportunity to use their free time in a positive aspect.
Analyzing the answers to the next question, we can draw conclusions and generalizations on the implementation of the tasks of specialized social and educational work.

Table 5

\begin{tabular}{|l|c|c|}
\hline \multicolumn{1}{|c|}{ Question/answers } & Amount & $\%$ \\
\hline \begin{tabular}{l|c|}
\hline \multicolumn{1}{|c|}{ 5. Do you agree that the educational and corrective measures provided for by the law can help prevent and overcome } \\
aggression?
\end{tabular} & 53 & 88.3 \\
\hline a) individual counseling with regard to the problems encountered & 11 & 18.3 \\
\hline b) group counseling & 49 & 81.7 \\
\hline c) training for education & 6 & 10.0 \\
\hline d) training for literacy & 21 & 35.0 \\
\hline e) training for the profession & 2 & 3.3 \\
\hline f) meeting religious needs &
\end{tabular}

The above-mentioned correction and prevention measures applied in correctional institutions receive a high degree of approval by convicts. The hypothesis that convicts prefer individual counseling when solving problems and current difficulties that arise in everyday life is confirmed. Another corrective measure that respondents point to is training and raising the level of education that allows them to understand the connections between thoughts and behavior and acquire creative thinking skills.

To fulfill the tasks set in the study, it is important to consider convicts' attitude toward labor.

Table 6

\begin{tabular}{|l|c|c|}
\hline \multicolumn{1}{|c|}{ Question } & Answers & Number of answers \\
\hline $\begin{array}{l}\text { 6. Do you agree that labor activity in prison helps prevent aggression } \\
\text { among convicts? }\end{array}$ & a) yes & 59 \\
\cline { 2 - 3 } & b) no & 1 \\
\hline
\end{tabular}

Labor activity as the work aimed at overcoming aggression is welcomed by all convicts but one. Professional qualification is another important measure of the entire process of resocialization carried out in correctional institutions $[1 ; 6]$. The principle of work as a duty and right is one of the most important elements of the subsequent re-socialization of convicts.

The next question gives an idea of how the established regime in the institution affects the aggressive behavior of convicts.

Table 7

\begin{tabular}{|l|c|c|}
\hline \multicolumn{1}{|c|}{ Question/answers } & Amount & $\%$ \\
\hline 7. Which of the following prison regimes is more important for preventing aggression? & \multicolumn{2}{|c|}{} \\
\hline a) long-term stay under a more relaxed regime & 48 & 80.0 \\
\hline б) short-term stay under a more strict regime & 13 & 21.7 \\
\hline
\end{tabular}

When asked about the duration of prison regime when overcoming aggression, respondents said that they prefer a more relaxed regime with a longer stay in prison, rather than the opposite option. Convicts adapt successfully if they have well learned the internal norms of joint stay in prison, if their work is effective and if they interact successfully in a group and community.

Table 8

\begin{tabular}{|l|c|c|}
\hline \multicolumn{1}{|c|}{ Question/answers } & Amount & $\%$ \\
\hline 8. What relationships do you consider to be most important in terms of preventing aggression? \\
\hline a) make friends with another convict & 23 & 39.7 \\
\hline b) make friends with a group of convicts & 0 & 0 \\
\hline c) maintain good relationships with all convicts & 53 & 91.4 \\
\hline
\end{tabular}


As for interpersonal relations, we note that in order to reduce tension and make their stay in a correctional institution more comfortable, convicts prefer to maintain good relations with those around them. The participation of con- victs in separate groups in conducting lectures, discussions, etc. is welcome.

Whether convicts prefer a fair punishment can be judged by the number of answers to the next question.

Table 9

\begin{tabular}{|l|c|c|}
\hline \multicolumn{1}{|c|}{ Question/answers } & Amount & $\%$ \\
\hline 9. What helps to prevent or stop aggression? & 37 & 71.2 \\
\hline a) fair punishment for the prison offense & 15 & 28.8 \\
\hline b) missed punishment due to non-detection of the violation & 15 &
\end{tabular}

We can state with confidence that in order to prevent aggressive reactions respondents prefer to receive a fair punishment for violating the established prison regime.

\section{Summary of the survey results}

The analysis of the survey results shows that the most frequent manifestations of aggression among convicts are physical violence against each other and the infliction of material damage. The results obtained show that the most common reasons for the aggressive reaction of convicts are misunderstandings between them and violations of their rights by the administration of the institution. When a person is incarcerated, their behavior changes significantly, so as to be in line with the new micro-social environment. Probably, it is a complicated process, and its violation leads to aggression, as evidenced by the results of the answers to the second question. The reasons lie in the personal characteristics and specific conditions of detention, as well as the extreme nature of the psychological situation. This raises the question of finding ways not only to control, but also to achieve personal changes that reduce aggressive behavior. Participation in cultural events and encouragement from the administration of the institution help convicts to endure more easily the difficulties of everyday life, motivate them to interact with other members of the group. The answers confirm the hypothesis about the positive attitude of convicts toward work and toward inclusion in programs for education and self-knowledge. In such a situation, training programs conducted in correctional institutions and, what is equally important, social support would produce an undeniable effect.

In order to reveal the causes of aggressiveness in convicts, we used the Buss-Durkee Hostility Inventory, which identifies the following types of aggressive reactions: assault - the use of physical force against another person; indirect aggression - actions implicitly directed at another person or at inanimate objects; irritability - increased nervousness, excitability, readiness to manifest negative reactions to minor stimuli; negativism - an oppositional manner in behavior, manifested in the range from passive rejection to active resistance and struggle; resentment - a negative feeling, which is based on a person's feelings about the injustice done to them (real or fictional), misunderstanding on the part of others, infringement of interests, hurt feelings of self-esteem; suspicion - a complex set of feelings manifested in a wide range: from distrust and caution in relation to other people to the belief that they are harmful; verbal aggression -the expression of negative feelings through verbal reactions (curses, threats, sarcasm); guilt - negative feelings associated with a mistake made, harm caused, with a sense of unfulfilled debt, often leading to a decrease in self-esteem.

Diagnostics using the above-mentioned test revealed the following dominant types of aggressive reactions in convicts: assault, indirect aggression, irritability, resentment, and verbal aggression. This was partially confirmed by the results of the questionnaire-based diagnostic examination.

\section{Key takeaways}

According to the results of the study, we draw the conclusions that confirm our hypotheses:

1. Aggression is a form of behavior that directly depends on the set of personal capabilities that determine and ensure the implementation of aggressive behavior by convicts.

2. The content of the criminogenic set of the personality includes character accentuations, life prospects that determine goals and future ideals, self-esteem and behavior features.

\section{Conclusion}

With the help of a questionnaire as a form of research, convicts get the opportunity to ex- 
press themselves creatively, which contributes to self-knowledge and the search for meaning. We note dissatisfaction with the needs for education, learning something new by going back to the past, and rehearsing new role models that reduce internal anxiety, which, in turn, leads to autonomy, confidence, and the desire for change. Effective management of aggression, as well as the achievement of changes in the convict's personality in relation to social competence, should be based on a broader strategy than the administrative-criminal approach. It includes psychocorrectional and socio-pedagogical positions. As R. Baron points out, the imminent punishment can indeed serve as an effective means of preventing aggression, but only if the aggressor is not in a state of extreme anger, if the punishment that they can expect is severe enough, and if the probability of its application is really high $[4 ; 11]$. Reformation and educational work supports the balance of self-esteem in convicts, and the level of their requirements reaches adequate parameters, which is directly related to the motivation for success and personality changes. The preservation and affirmation of one's Self through the destruction of the other's Self is the result of a number of unconscious motives that arise in the presence of aggressive affect, psychological inferiority, and pathological personality traits.

\section{REFERENCES}

1. Andreeva L.M. Social cognition and interpersonal interaction. Sofia, 2007. 528 p. ISBN 978-954-072-515-4.

2. Batarshev A.V. Diagnostika temperamenta $i$ kharaktera [Diagnostics of temperament and character]. Second edition. Saint Petersburg: Peter, 2007. 368 p. ISBN 978-5-91180-484-8.

3. Batarshev A.V. Complete psychodiagnostics of an individual. Soft-press publ., 2008. 496 p. ISBN 978-954-685-740-8.

4. Baron R., Richardson D. Agressiya [Human Aggression]. Saint Petersburg: Piter, 2014. 416 p. ISBN 978-5-496-00994-2.

5. Gercheva-Nestorova G., Nedyalkova Y. Applications of psychology in management. Varna Free University "Chernorizets Hrabar", 2019. ISBN 978-954-715-678-4.

6. Gercheva-Nestorova G. Social communications. Varna Free University "Chernorizets Hrabar", 2012. ISBN 978-954-715-549-7. 7. Dmitriev Yu.A., Kazak B.B. Penitentsiarnaya psikhologiya: uchebnik dlya obrazovatel'nykh uchrezhdenii Ministerstva yustitsii Rossiiskoi Federatsii [Penitentiary psychology: textbook for educational institutions of the Ministry of Justice of the Russian Federation]. Rostov-on-Don: Feniks, 2007. 681 p. ISBN 978-5-222-12254-9.

8. Ivanov P. Methodology and history of social psychology. Varna Free University "Chernorizets Hrabar", 2005. ISBN 954715-267-X.

9. Nedyalkova Y. Aggression: theoretical and empirical measurements. Coping strategies. Varna Free University "Chernorizets Hrabar", 2020. ISBN 978-954-715-705-7.

10. Corsini R.J., Auerbach A.J. Psikhologicheskaya entsiklopediya [Concise Encyclopedia of Psychology]. Translated from English. Second edition. Saint Petersburg: Piter, 2003. 1094 p. ISBN 5-272-00018-8.

11. Psikhologiya chelovecheskoi agressivnosti. Khrestomatiya [Psychology of human aggressiveness. Textbook]. Minsk: Kharvest, 2005. 653 p. ISBN 985-13-0967-2.

12. Spirkin A. Soznanie i samosoznanie [Awareness and self-awareness]. Moscow, 1972.

13. Stamatov R., Minchev B. Human psychology. Hermes, Plovdiv, 2003, 2005. ISBN 954-26-0101-8.

14. Stamenkova N. Professional psychodiagnostics. Varna Free University "Chernorizets Hrabar", 2005. 266-1.

15. Stoyanov V. et al. Experimental psychology. Varna Free University "Chernorizets Hrabar”, 2003. ISBN 954-75-186-X. 16. Stoyanova S. et al. Methodological guidelines for conducting empirical psychological research. Blagoevgrad: Neofit Rilski Publ., 2014. ISBN 978-954-680-930-8.

17. Frankl V. The Doctor and the Soul. Pleven: Lege Artis, 2001. 260 p. ISBN 954-9933-16-4.

18. Khadzhiyski M. Psychological counseling in penitentiary practice. Veliko Tarnovo: Faber, 2001. 283 p. ISBN 954-9541-89-4.

19. Tsolova M. Personality of the offender - theoretical dimensions and empirical aspects. Varna, 2012. 156 p. ISSN $1314-0507$.

\section{INFORMATION ABOUT THE AUTHOR}

YOANNA M. NEDYALKOVA - Ph.D., Associate Professor, Department of Psychology, Varna Free University "Chernorizets Hrabar", Varna, Bulgaria. ORCID: https://orcid.ord/0000-0002-7314-625X, e-mail: retrojonni@abv.bg 